\title{
Cenozoic palaeogeography and isochores predating the Neogene exhumation of the eastern North Sea Basin
}

\author{
Peter Japsen, Erik S. Rasmussen, Paul F. Green, Lars Henrik Nielsen and Torben Bidstrup
}

Denmark is a key region for studies of the Cenozoic development of Scandinavia because Paleocene to Upper Miocene sediments crop out across the country and because it is possible to correlate these occurrences with the up to $3 \mathrm{~km}$ thick Cenozoic succession of the North Sea Basin. However, the reason why the Cenozoic deposits occur close to the surface of the Earth in Denmark is that the sediments have been exhumed from their cover of younger rocks. This implies that a reconstruction of the Cenozoic development across Denmark - involving both burial and exhumation - must rely on sedimentological and seismic studies of preserved sediments as well as on physical parameters that may yield evidence of the postdepositional history of the sediments now at the surface. Only if the burial and exhumation history of the basins can be deciphered is it possible to infer the geological development in the Scandinavian hinterland where Cenozoic sediments are rarely preserved.

We have identified four Mesozoic-Cenozoic palaeothermal phases related to burial and subsequent exhumation, and one phase reflecting climate change during the Eocene. This is based on new apatite fission-track analyses (AFTA) and vitrinite reflectance data from eight Danish wells (Japsen et al. 2007a). The study combined thermal history reconstruction with exhumation studies based on palaeoburial (sonic velocity), stratigraphic and seismic data (cf. Japsen \& Bidstrup 1999; Green et al. 2002; Nielsen 2003; Rasmussen 2004; Japsen et al. 2007b). Two of the exhumation phases occurred during the mid-Jurassic and the mid-Cretaceous. In this study we focus on the Cenozoic development and on the early and late Neogene exhumation phases during which up to $1 \mathrm{~km}$ of sediments were removed across most of the Danish region (Fig. 1).

\section{Early and late Neogene exhumation}

A major phase of exhumation of the parts of the eastern North Sea Basin adjacent to the presently exposed basement areas in Norway and Sweden began between 30 and $20 \mathrm{Ma}$ ago according to the AFTA data (Fig. 1). We suggest that this phase corresponds to the Oligocene-Miocene unconformity (c. $24 \mathrm{Ma}$ ). Prior to this early Neogene exhumation phase, the Mesozoic sediments in the Felicia-1 well were at maximum burial. The maximum burial of the Mesozoic sediments in the Hans-1 well occurred during the mid-Cretaceous, prior to inversion along the Sorgenfrei-Tornquist Zone, whereas maximum burial during the Cenozoic occurred prior to the early Neogene exhumation phase.

Late Neogene exhumation began between 10 and $5 \mathrm{Ma}$ ago according to the AFTA data from e.g. the Års-1 and Felicia-1 wells. Only one sample limits the onset of this phase to begin before $5 \mathrm{Ma}$, and the onset of the exhumation probably began in the early Pliocene at $c .4 \mathrm{Ma}$ as suggested by the prominent unconformity of this age. After $4 \mathrm{Ma}$ significant progradation from Scandinavia into the North Sea Basin and increased subsidence in the central North Sea were initiated. A section of 450-850 m was removed in the central part of the Norwegian-Danish Basin in association with this reshaping of the North Sea Basin. The exhumation affected extensive regions where Neogene strata are truncated, and in southern Norway and Sweden a sub-Cretaceous etched surface was reexposed along the coasts (Lidmar-Bergström et al. 2000).

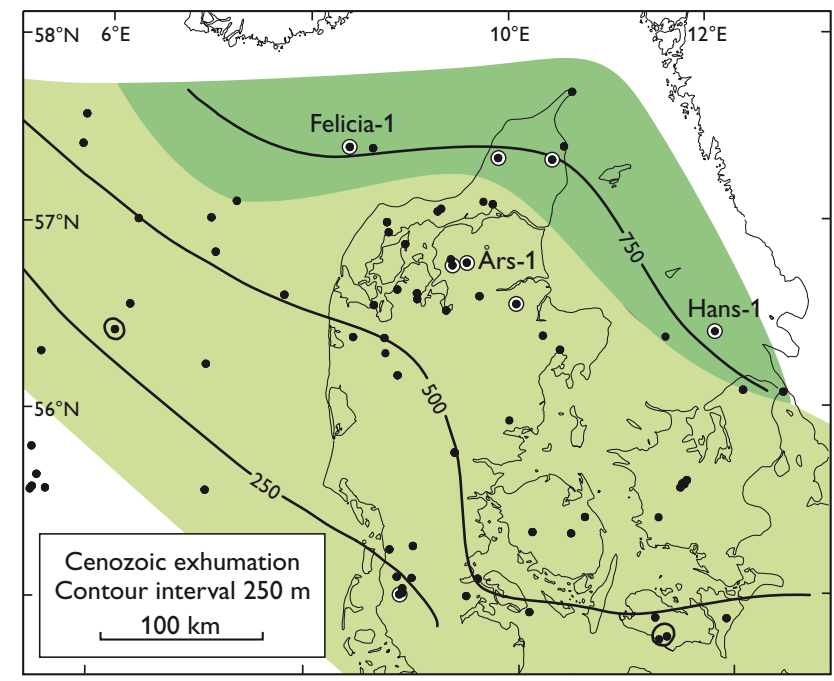

Maximum burial

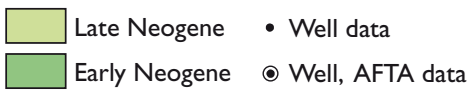

Fig. 1. Thickness of the section removed during Cenozoic exhumation. Maximum burial of the Mesozoic sediments took place during the late Neogene in most of the study area. Near the present coasts of Norway and Sweden, however, maximum burial occurred subsequent to deposition of the Oligocene wedges and prior to early Neogene exhumation. Only in the Hans-1 well did maximum burial occur during the Mesozoic. Modified from Japsen et al. (2007a). 

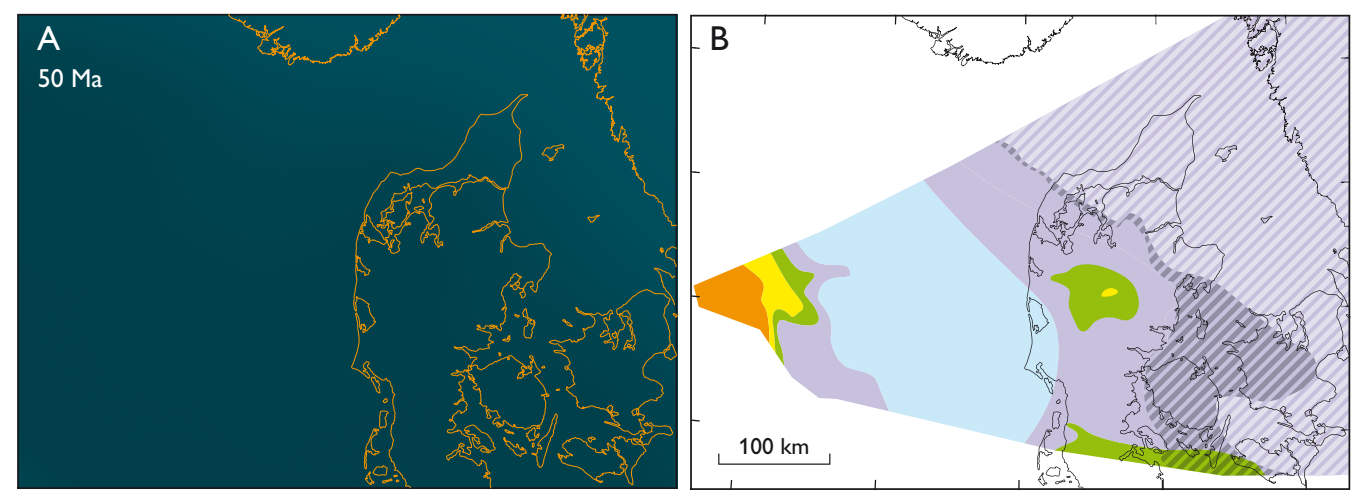

Fig. 2. A: Early Eocene palaeogeography, $50 \mathrm{Ma}$ B: Upper Paleocene Eocene isochore prior to Neogene exhumation. Modified from Japsen $e t$ al. (2007a).
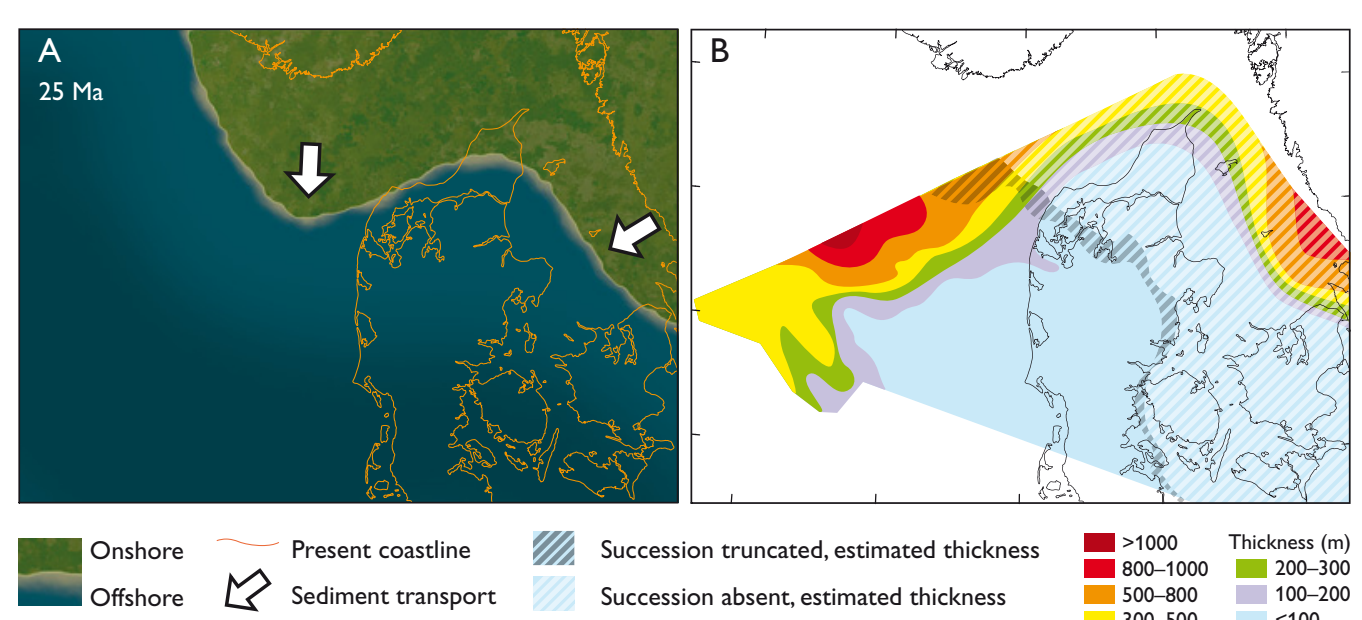

Fig. 3. A: Late Oligocene palaeogeography, $25 \mathrm{Ma}$. B: Oligocene isochore prior to Neogene exhumation. Modified from Japsen et al. (2007a).

\section{Maps of palaeogeography and isochores prior to the Neogene exhumation phases}

We have compiled a series of maps to illustrate the Cenozoic development of the eastern North Sea Basin (Figs 2-6). The isochore maps are based on present thicknesses and estimates of the removed sections constrained by the total amount of section removed by Cenozoic exhumation. The estimates of the removed sections of specific ages are furthermore constrained by the known geology and our interpretation of the depositional pattern. Each isochore map shows the thicknesses prior to the first phase of exhumation that affected the distribution of the unit; i.e. prior to early Neogene exhumation (starting at c. $24 \mathrm{Ma}$ ) in the case of the Palaeogene units and prior to late Neogene exhumation (starting at $c .4 \mathrm{Ma}$ ) for the Neogene units. The palaeogeographical maps show the distribution of onshore and offshore areas separated by the coastline based on the known geology. In the areas where the deposits of a given age have been removed, the map has been drawn from an estimate based on our interpretation of the depositional system and on the inferred burial and exhumation history.

In the early Eocene, the study region was covered by a deep sea as demonstrated by hemipelagic deep-marine sedimentation that lasted until latest Eocene times (Fig. 2A;
Heilmann-Clausen et al. 1985; Michelsen et al. 1998). Parts of Scandinavia were probably covered by Eocene sediments because Eocene deposits within the Norwegian-Danish Basin contain a deep marine fauna close to the Sorgenfrei-Tornquist Zone with no signs of a near-shore fauna (C. Heilmann-Clausen, personal communication 2005). Furthermore, reworked Eocene dinocysts and clasts of Eocene muds interbedded with Miocene deltaic sediments in Denmark clearly indicate the presence of marine Eocene deposits in the Scandinavian hinterland (Rasmussen 2004). The thickness of the Upper Paleocene - Eocene sediments that was removed during the Neogene rise of Scandinavia was probably limited (<200 m; Fig. 2B).

During the Oligocene, major clastic wedges prograded into the Norwegian-Danish Basin from present-day Norway (Fig. 3A; Michelsen et al. 1998; Clausen et al. 1999; Faleide et al. 2002). This change in depositional environment from Eocene times indicates a phase of tectonic uplift of southern Norway (c. 33 Ma) (e.g. Michelsen et al. 1998; Lidmar-Bergström et al. 2000; Faleide et al. 2002). This tectonic activity is shown by reactivation of faults on the Ringkøbing-Fyn High and by movements of salt structures in the Norwegian-Danish Basin (Rasmussen 2004). We suggest that a thick succession of Oligocene shelf and delta sediments that 
Fig. 4. A: Middle

Miocene palaeogeogra-

isochore prior to late

Neogene exhumation.

Modified from Japsen et al. (2007a). phy, 15 Ma. B: Lower -

lower Middle Miocene
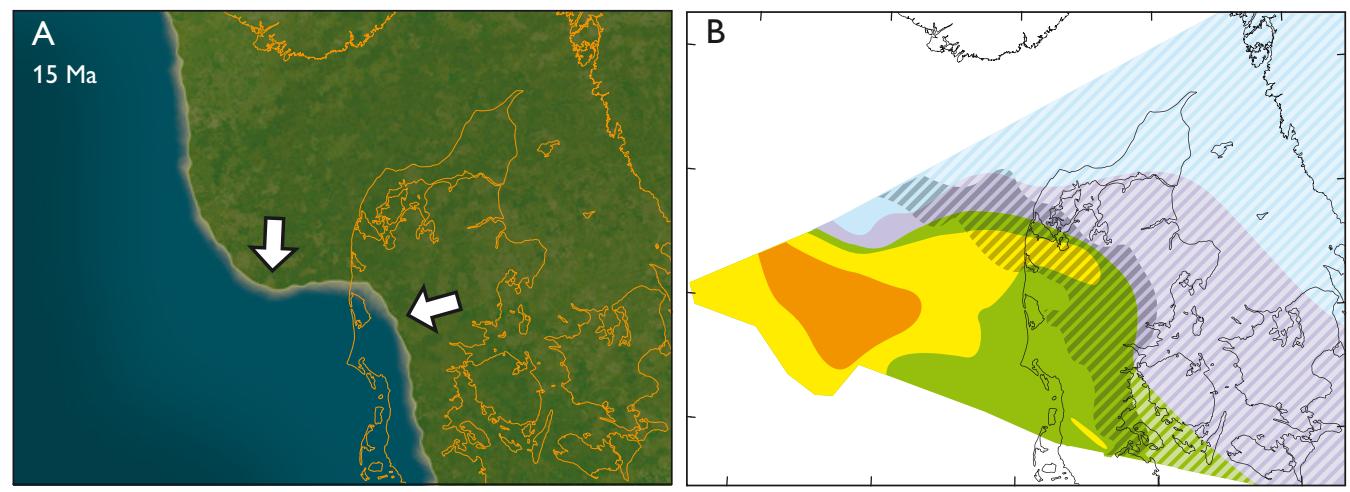

Fig. 5. A: Late Miocene palaeogeography, $12 \mathrm{Ma}$. B: Upper Middle - lower Upper Miocene isochore prior to late Neogene exhumation. Modified from Japsen et al. (2007a).

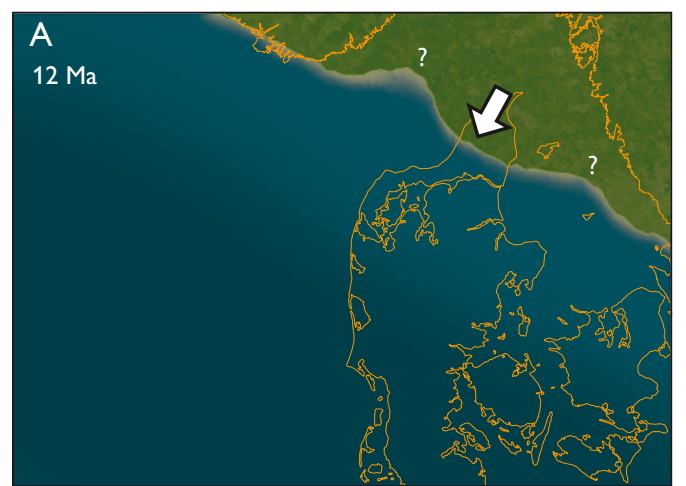

prograded southwards from southern Norway and westwards from southern Sweden made up a substantial part of the section that was removed during the Neogene exhumation at the locations of the Felicia-1 and Hans-1 wells, respectively (>1 km) (Fig. 3B).

During the early Miocene, deltas prograded to the south and south-west and reached a thickness up to $300 \mathrm{~m}$ (Fig. 4A). The deposition of coarse-grained sediments reached the southern part of the Norwegian-Danish Basin and the Ringkøbing-Fyn High during the Neogene (Rasmussen 2004). These prograding systems reflect a redistribution of sediments caused by uplift in the Scandinavian hinterland that resulted in the early Neogene exhumation near the craton. The occurrence of both immature and mature sediments reflects erosion of weathered as well as newly exposed basement. In the Danish area, the early Miocene tectonic activity is demonstrated by coarse-grained, braided fluvial systems and later by a sudden increase in the heavy mineral content at c. $17 \mathrm{Ma}$ (Rasmussen 2004). The thickness of the Lowerlower Middle Miocene sediments that was removed during late Neogene exhumation was probably limited $(<500 \mathrm{~m})$, because mainly the onshore part of these deposits were affected by exhumation (Fig. 4B).

In the middle Miocene, at c. $15 \mathrm{Ma}$, a distinct marine flooding of the area took place, and up to $150 \mathrm{~m}$ of clayey sediments were deposited in south-western Denmark during the middle-late Miocene (Fig. 5A) (Rasmussen 2005). The flooding was caused partly by eustatic sea-level rise related to the mid-Miocene climatic optimum and partly by increased subsidence in the eastern North Sea Basin in the late Miocene (Rasmussen 2004). The thickness of the upper Middle lower Upper Miocene sediments that was removed during late Neogene exhumation was limited (<200 m; Fig. 5B).

At the end of the Miocene resumed delta progradation from north-east and in particular the east occurred (Fig. 6A) (Rasmussen 2005). The infilling of the North Sea Basin continued during the Pliocene where up to $500 \mathrm{~m}$ were deposited in the central North Sea Basin. Substantial thicknesses $(<500 \mathrm{~m})$ of upper Upper Miocene - Pliocene sediments were removed during late Neogene exhumation across an extensive region of the eastern North Sea (Fig. 6B).

\section{Summary and implications}

This study emphasises that the tectonic development of a region cannot be reconstructed solely on evidence from the sedimentary record. Such reconstructions need also to be based on the record of physical indicators of palaeothermal and palaeoburial phases related to the former presence of geological units now removed. We have found evidence for three tectonic phases that have affected southern Scandinavia during the Cenozoic: (1) A phase that began at the Eocene-Oligocene transition at $c .33 \mathrm{Ma}$ as indicated by the onset of progradation of clastic wedges away from southern Norway and 

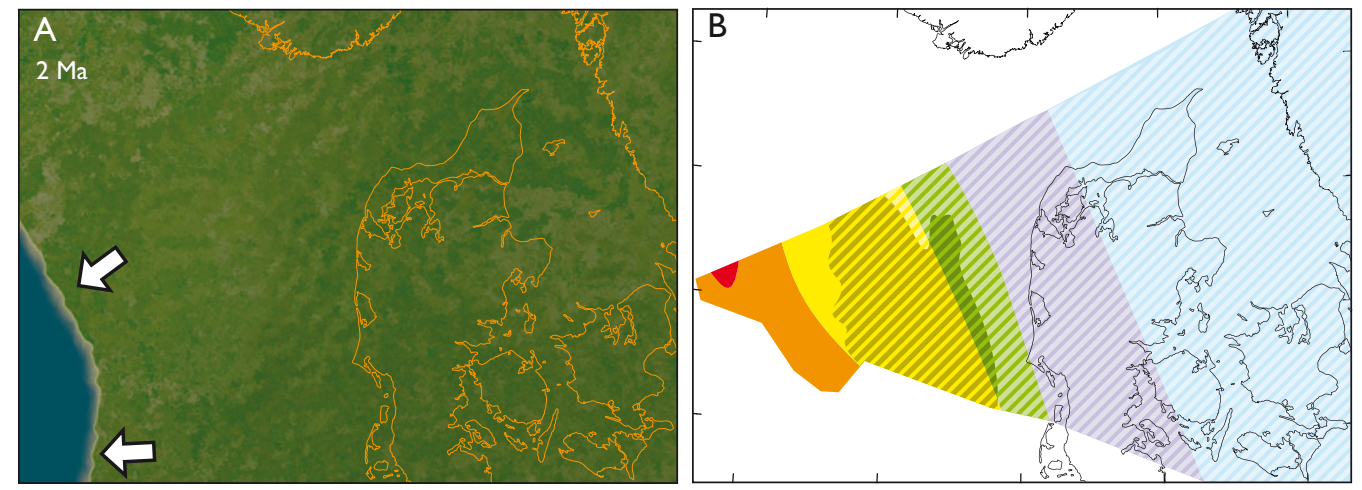

Fig. 6. A: Pliocene palaeogeography, 2 Ma. B: Upper Upper Miocene - Pliocene isochore prior to late Neogene exhumation. Modified from Japsen et al. (2007a).

inferred progradation away from southern Sweden. (2) A phase that began at the Oligocene-Miocene transition at $c$. $24 \mathrm{Ma}$, as indicated by early Neogene exhumation of the areas adjacent to the presently exposed basement areas and by early Miocene coarse-grained braided fluvial systems south of Scandinavia. (3) A phase that began in the early Pliocene at $c$. $4 \mathrm{Ma}$, as indicated by the widespread, late Neogene exhumation, the intra-Pliocene unconformity and subsequent tilting of the Neogene succession in the eastern North Sea.

These phases are consistent with the stratigraphy in the north-east Atlantic Ocean (Stoker et al. 2005) and around southern Norway (e.g. Michelsen et al. 1998; Faleide et al. 2002; Rasmussen 2004). The observations thus suggest that southern Norway, with peaks higher than $2 \mathrm{~km}$ above sea level, emerged during several phases since Eocene times, when a deep ocean covered much of the region.

\section{References}

Clausen, O.R., Gregersen, U., Michelsen, O. \& Sørensen, J.C. 1999: Factors controlling the Cenozoic sequence development in the eastern parts of the North Sea. Journal of the Geological Society of London $\mathbf{1 5 6}$ 809-816.

Faleide, J.I., Kyrkejbø, R., Kjennerud, T., Gabrielsen, R.H., Jordt, H., Fanavoll, S. \& Bjerke, M. 2002: Tectonic impact on sedimentary processes during Cenozoic evolution of the northern North Sea and surrounding areas. In: Doré, A.G. et al. (eds): Exhumation of the North Atlantic Margin: Timing, Mechanisms and Implications for Petroleum Exploration. Geological Society Special Publications (London) 196, 235-269.

Green, P.F., Duddy, I.R. \& Hegarty, K.A. 2002: Quantifying exhumation from apatite fission-track analysis and vitrinite reflectance data: precision, accuracy and latest results from the Atlantic margin of NW Europe. In: Doré, A.G. et al. (eds.): Exhumation of the North Atlantic margin: timing, mechanisms and implications for petroleum exploration. Geological Society Special Publications (London) 196, 331-354.
Heilmann-Clausen, C., Nielsen, O.B. \& Gersner, F. 1985: Lithostratigraphy and depositional environments in the upper Palaeocene and Eocene of Denmark. Bulletin of the Geological Society of Denmark 33, 287-323.

Japsen, P. \& Bidstrup, T. 1999: Quantification of late Cenozoic erosion in Denmark based on sonic data and basin modelling. Bulletin of the Geological Society of Denmark 46, 79-99.

Japsen, P., Green, P.F., Nielsen, L.H., Rasmussen, E.S. \& Bidstrup, T. 2007a: Mesozoic-Cenozoic exhumation in the eastern North Sea Basin: a multi-disciplinary study based on palaeo-thermal, palaeo-burial, stratigraphic and seismic data. Basin Research 19, 451-490.

Japsen, P., Mukerji, T. and Mavko, G. 2007b: Constraints on velocitydepth trends from rock physics models. Geophysical Prospecting 55 , 135-154.

Lidmar-Bergström, K., Ollier, C.D. \& Sulebak, J.C. 2000: Landforms and uplift history of southern Norway. Global and Planetary Change 24, 211-231.

Michelsen, O., Thomsen, E., Danielsen, M., Heilmann-Clausen, C., Jordt, H. \& Laursen, G. 1998: Cenozoic sequence stratigraphy in the eastern North Sea. In: de Graciansky, P.-C. et al. (eds): Mesozoic and Cenozoic sequence stratigraphy of European basins. Society of Economic Paleontologists and Mineralogists Special Publication 60, 91-118.

Nielsen, L.H. 2003: Late Triassic - Jurassic development of the Danish Basin and Fennoscandian Border Zone, southern Scandinavia. In: Ineson, J. \& Surlyk, F. (eds): The Jurassic of Denmark and Greenland. Geological Survey of Denmark and Greenland Bulletin 1, 459-526.

Rasmussen, E.S. 2004: The interplay between true eustatic sea-level changes, tectonics, and climatical changes: What is the dominating factor in sequence formation of the Upper Oligocene-Miocene succession in the eastern North Sea Basin, Denmark? Global and Planetary Change 41, 15-30.

Rasmussen, E.S. 2005: The geology of the upper Middle - Upper Miocene Gram Formation in the Danish area. Palaeontos 7, 5-18.

Stoker, M.S., Praeg, D., Shannon, P.M., Hjelstuen, B.O., Laberg, J.S., Nielsen, T., van Weering, T.C.E., Sejrup, H.P. \& Evans, D. 2005: Neogene evolution of the Atlantic continental margin of NW Europe Lofoten Islands to SW Ireland: anything but passive. In: Doré, A.G. \& Vining, B.A. (eds): Petroleum geology: North-West Europe and global perspectives. Proceedings of the $6^{\text {th }}$ Petroleum Geology Conference, 1057-1076. London: Geological Society.

Zachos, J.C., Pagani, M., Sloan, L.C., Thomas, E. \& Billups, K. 2001: Trends, rythms, and aberrations in global climate $65 \mathrm{Ma}$ to present. Science 292, 686-693.

\section{Authors' addresses}

P.J., E.S.R., L.H.N. \& T.B., Geological Survey of Denmark and Greenland, Øster Voldgade 10, DK-1350 Copenhagen K, Denmark. E-mail: pj@geus.dk P.F.G., Geotrack International, 37 Melville Road, Brunswick West, Victoria 3055, Australia. 